\title{
Jurassic ammonite biochronology of Greenland and the Arctic
}

\author{
JOHN H. CALLOMON
}

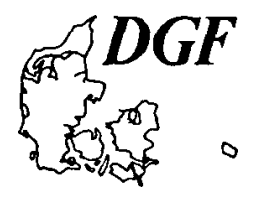

Callomon, J.H.: Jurassic ammonite biochronology of Greenland and the Arctic. Bulletin of the
Geological Society of Denmark, Vol. 41, pp. 128-137. Copenhagen, 1994-11-30.
https://doi.org/10.37570/bgsd-1995-41-12

The standard biochronological chronostratigraphy of the Phanerozoic and of its conjugate time-scale has been refined over a century and a half by a process of top-down subdivision in a hierarchy of successively smaller units. The finest units currently accepted, at the seventh level of the hierarchy, are the Subzones widely used in the Jurassic, thanks to that System's exceptional guide-fossils, its ammonites. But the time-resolution even at this level is not yet at the limits attainable through biostratigraphy. The ultimate observable is a characteristic faunal horizon, defined as a fossiliferous stratum or succession of strata within whose specified fossil assemblages no further evolutionary - as opposed to compositional - changes can be distinguished. Such a horizon represents effectively a biochronological instant. The fossil record is resolved into a succession of such instants, recognizable perhaps in as little as a single section and separated by time-gaps of unknown duration. The time-intervals between the ages $t$ of successive horizons represent the limits of temporal resolution, $\delta t$, discemible by means of fossils. They depend strongly on the fossils employed and may be expressed in terms of their secular resolving-power, $R=t / \delta t$. Some estimates selected from the Mesozoic and Palaeozoic are compared in a Table.

The geographical limits of time-correlation by means of fossils are often set by bioprovincial endemisms of the organisms of which the fossils are the remains. The biochronology, and any standard chronostratigraphical scale based upon it, has therefore to be worked out in each Province separately, and such provincial scales correlated in regions of provincial overlap, if known. An excellent example is found in the Middle and Upper Jurassic of East Greenland. Its ammonite biochronology is today represented by some 100 faunal horizons. But the ammonites are largely confined to a sharply segregated Arctic, Boreal Province, for which they now provide a standard zonation. Detailed correlations with the primary standards of Europe continue to range from the problematical to the impossible.

John H. Callomon, University College London, 20 Gordon Street, London WC1H OAJ, U.K. July 19th, 1994.

\section{Introduction: dating rocks by means of fossils}

To reconstruct the history of the Earth, all we need to do is to measure the ages of the rocks we see around us. This allows us to present the history as a simple compilation of what has occurred, and such compilations continue to form the basis of text-books on historical geology. We now have, moreover, powerful methods of dating rocks directly, through the measurement of the products of radioactive decay. But alas, as we all know, these direct methods are applicable to only a small minority of cases. In the pre-Phanerozoic, representing seven-eighths of the Earth's history, they are indeed all we have.

Fortunately, in the Phanerozoic, other, indirect methods of much greater power and versatility are available, based on the biostratigraphy of fossils in stratified sedimentary rocks. That these methods cover only the youngest eighth of the Earth's history may at first seem a serious shortcoming. But the reason why this is not so is that we are in fact less interested in a mere catalogue of events than in a detailed understanding of the underlying processes of which they were the expression: in a genetic history of the Earth. Each process has a rate specified by a characteristic rate-constant, and what makes geology so fascinating is the enormous dynamic range of the temporal hierarchy of processes involved. At one extreme, we follow plate megatectonics through continental drift and ocean-floor spreading over quasi-cyclical periods of $10^{8}$ years. At the other, we interpret sedimentary structures in terms of storm-deposits, submarine slumps, current-bedding or bioturbation on scales of $10^{-2}-10^{+2}$ years. In between, we may be interested in macrotectonic mountain-building, basinal sequence-stratigraphy, or steps in the evolution of life itself, on scales of $10^{4}-10^{6}$ years. Clearly, all these fit easily into the duration of the Phanerozoic, some $10^{8.5}$ years, and it may have become trivial to remind ourselves that by far the greatest part of what we know about the evolution of the Earth has come from the study of Phanerozoic rocks, and of their sediments in particular. 
Table 1. Rock-time duality and the hierarchy of standard chronostratigraphy and geochronology.

\begin{tabular}{lll}
\hline Level & Rock & Time \\
\hline I & Eonothem & Eon \\
II & Erathem & Era \\
III & System & Period \\
IV & Series & Epoch \\
V & Stage & Age \\
VI & Zone & Chron \\
VII & Subzone & Subchron \\
\hline
\end{tabular}

It is worth briefly recalling the five steps in the argument involved in dating rocks stratigraphically. The first and basic observation is that of beds specified by heights in a succession, their thicknesses and their composition - their lithostratigraphy; and, if composition includes fossils, their biostratigraphy. The next step introduces Steno's Principle of Superposition (1669), which states that in a normal succession of sediments, the higher-lying are the younger. This transforms a static description in terms of height into a dynamic one, in terms of time - local relative time - and is an interpretation. Specification of rocks in a stratified succession according to their relative ages we refer to today as their chronostratigraphy, although this term appears only to have been first explicitly introduced by Hedberg (1954). The third step involves the linking of local successions through time-correlations. These allow the ages of rocks at one place to be compared with those at another. The fourth step then becomes the synthesis of a standard time-ordered succession of rocks, correlation with which allows any local

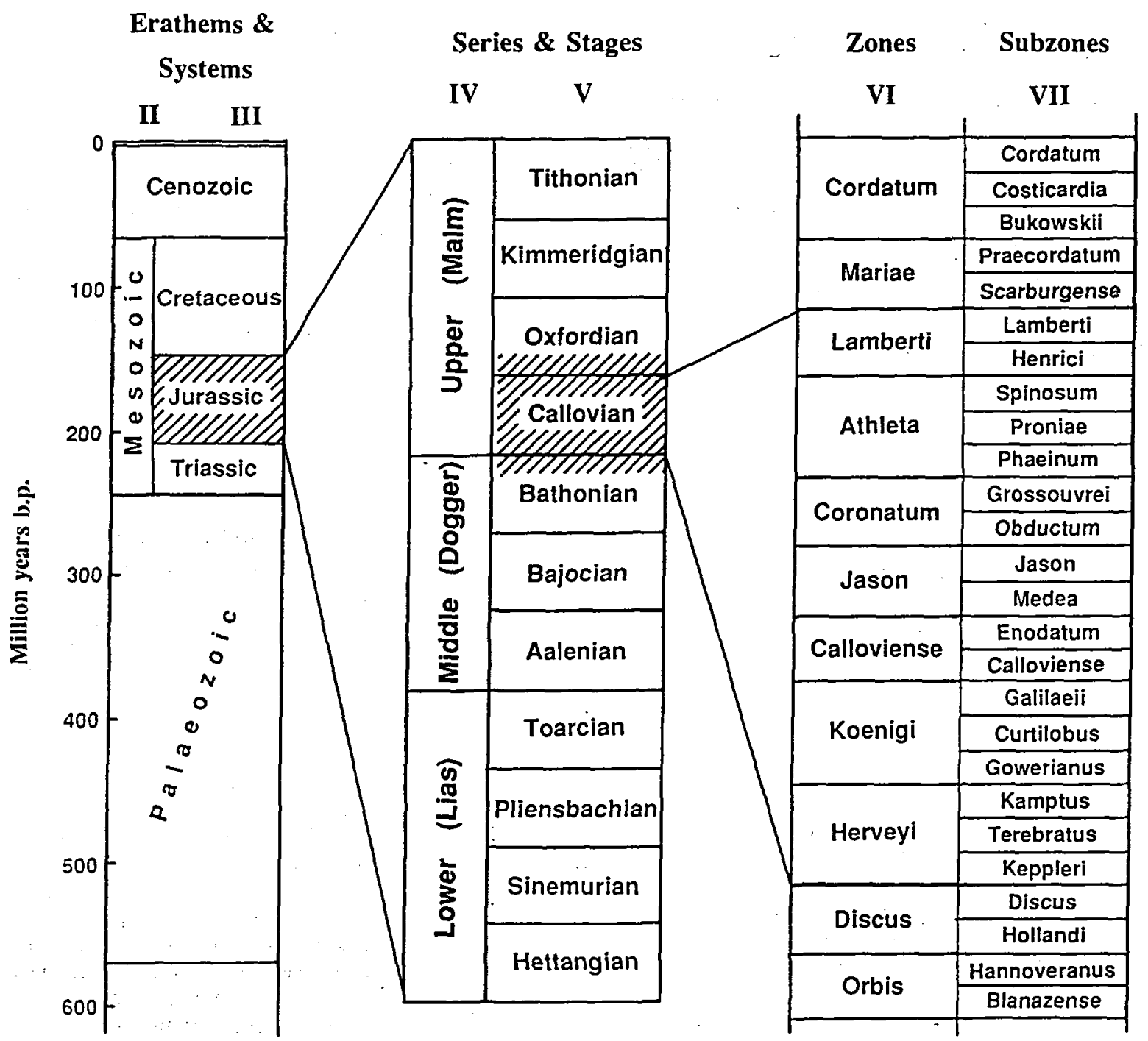

Fig. 1. Standard chronostratigraphic subdivision of the Jurassic down to the lowest level, of Subzones. 
rock to be dated in terms of its relative position in the implied conjugate chronostratigraphic time-scale. Only in the fifth and final step is this standard chronostratigraphic time-scale calibrated in absolute terms, in years, by radioactive methods.

The critical step is the third, that of time-correlation. It is here that biostratigraphy has made its greatest contribution based on the Principle of Biosynchroneity, usually attributed to William Smith: rocks containing similar fossils are of the same age. Here, "the same" has of course to be qualified to take account of the fact that fossil species have stratigraphical ranges. Some fossil species have shorter ranges than others and are therefore more closely time-diagnostic. Those that are good in this respect were called "Leit-Muscheln" by v. Buch (1839)our guide-fossils of today. The identification of good guide-fossils is something of an art, as all biostratigraphers will attest, and proceeds largely by trial and error. The intense efforts of a century and a half have been devoted to the unravelling of fossil biochronology with ever-increasing refinement and versatility, using the most diverse fossil groups of organisms applied to a very wide range of problems and circumstances.

Among the purposes to be achieved, two underlying ones stand out. The first is that of direct time-correlation itself. We wish to know as precisely as possible whether events represented by rocks at one place were synchronous with, preceded by or succeeded by those of another - hence, to determine relative ages. To this end, much effort has gone into the refinement of the standard Phanerozoic chronostratigraphical time-scale and its associated rock-units as we know them today. Refinement has been by successive subdivision of what is visualized as a complete and continuous geological column down a hierarchy of ever finer units and this hierarchy is recapitulated in Táble 1. The lowest steps in the hierarchy so far (level VII) have been introduced in the Mesozoic, through the fortunate circumstances of its exceptional guide-fossils, the ammonites, but other parts of the Phanerozoic are rapidly catching up (see below). A part of the Jurassic hierarchy is shown graphically in fig. 1 .

Looking at fig. 1, there are three points to note. Firstly, standard chronostratigraphical units are defined in terms of their bounding time-planes, represented by the horizontal lines between boxes making up the scales. These time-planes are defined typologically (in principle, at least) by "Golden Spikes" in a type section. Secondly, the units are recognized in the field, and rocks dated by being assigned to them, not by means of the defining timeplanes themselves but by means of what lies between them, by means of the biozones of their characteristic guide-fossils. This distinction is important, because a particular bed of rock usually represents a duration of time, itself unknown, that is shorter than the duration of the chronostratigraphical unit to which it is assigned. To that extent, therefore, the precision of a correlation, or of a dating, is limited to the time-duration of the unit to which the rock is assigned. All geological time-correla- tions are approximations. If, for instance, rocks at two localities are assigned to the same standard Zone, all that can be said is that their ages cannot differ by more than the duration of that Zone. For many geological problems this may of course be sufficient. It can cover the problems connected with the slower processes discussed above, e.g. those of regional tectonics. Thirdly, although fig. 1 is drawn to an absolute time-scale, in years, at the left, this is of only rather general interest and quantitatively meaningful at the higher levels of the hierarchy. It is largely irrelevant to most practical geological problems, in which we need to date rocks at the level of Stages at least, and preferably at finer levels than that. In Phanerozoic stratigraphy, the primary reports of dates and ages are rarely, if ever, expressed in years. The geological history of the Alps, for instance, was completely unravelled without a single absolute age-determination.

But are the time-durations of the lowest members of the standard hierarchy - in the Mesozoic, the Subzones at the limit of the time-resolution that can be achieved by means of fossils? The answer is emphatically no. Standard chronostratigraphical units being designed as the vehicle for geographically distant time-correlations, to be useful they have to be defined in such a way as to be recognizable over corresponding distances. In the case of Jurassic Subzones, this means over distances of Continental dimensions, of $1000-2000 \mathrm{~km}$ or more. But locally, even finer time-resolutions may be discernible in the fossil record than those represented by successive Subzones. They may, moreover, also be of great interest, but for different reasons: they can give insights into correspondingly faster geological processes, e.g. those of basinal sedimentation. At the limit, the finest discernible time-intervals resolved in even a single section can be of great value. An example would be in the study of the evolution of the guide-fossils themselves. "Missing links" are always first discovered at a single locality.

\section{Geological time-resolution by means of fossils}

The second of the two basic purposes for which biostratigraphy may be used is therefore not the measurement of geological ages themselves but of their differentials: the determination of the smallest time-intervals that can be resolved by means of fossils. This requires a change of approach. It becomes important to distinguish between the time-durations represented by beds with distinguishable fossil assemblages and the time-intervals between their formation. The basic biostratigraphical unit has come to be called a characteristic faunal horizon (Callomon 1964, 1985a,b; for further reviews, see 1994, 1995): 
Table 2. Estimates of smallest resolvable time-intervals.

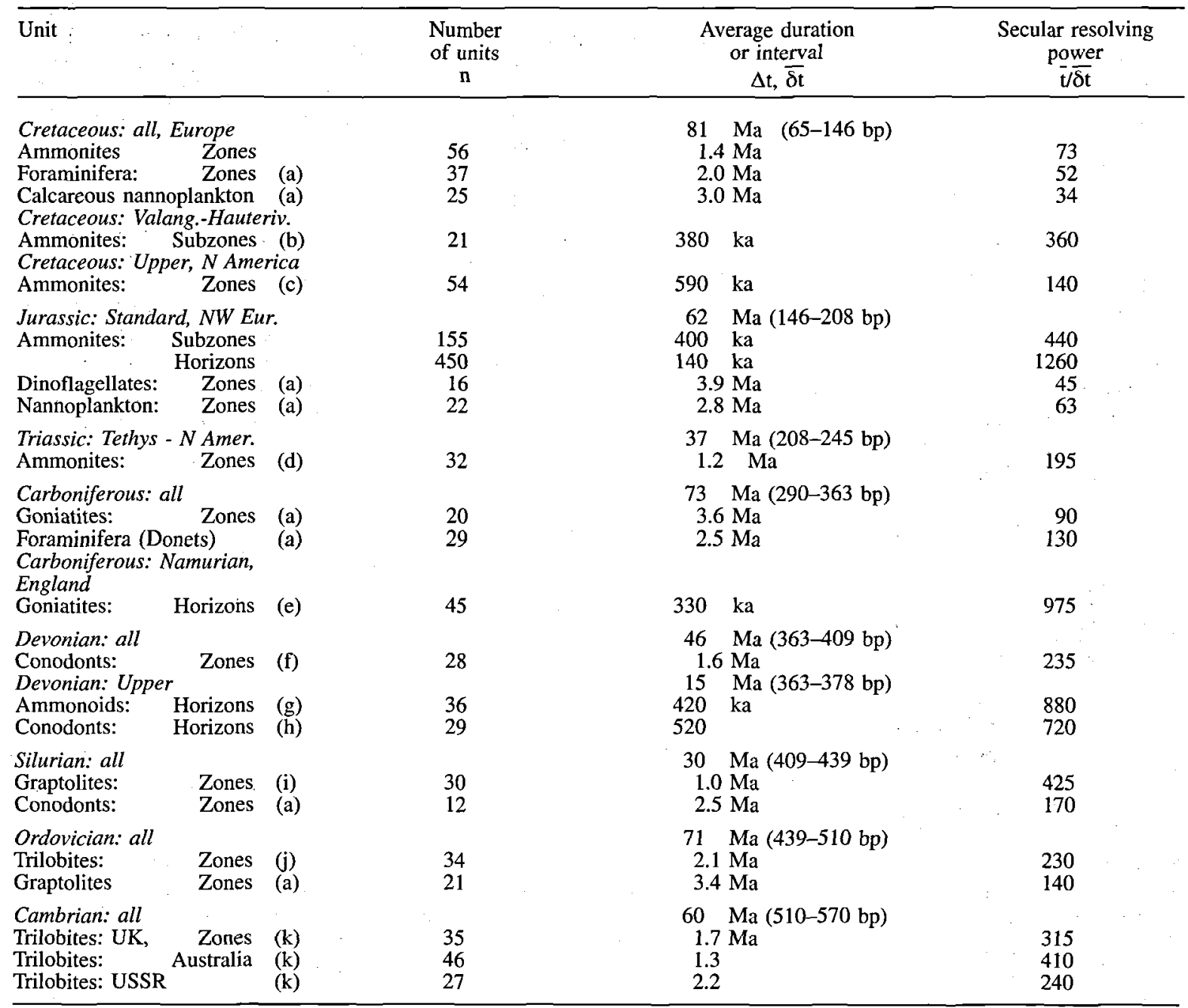

Absolute ages taken from Cambridge GTS 89 (Harland et al. 1990).

Sources: (a) Harland et al. 1990. - (b) Kemper 1978, N Germany. - (c) Obradovich \& Cobban 1975. - (d) Tozer 1984. - (e) Ramsbottom 1977, Riley in Cope 1993. - (f) Cited in (a), and see Aldridge 1987, Sweet 1988. - (g) Becker 1992. - (h) Ziegler 1974, Ziegler \& Sandberg 1990. - (i) Rickards 1976. - (j) Cited in (a), and see Thomas et al. 1984.

- (k) See (j) and Palmer 1977.

a faunal (or floral) horizon is a bed or series of beds, characterized by a specified fossil assemblage, within which no further significant morphological differences in the fossils can be stratigraphically resolved.

"Significant" implies evolutionary change rather than change in composition of ecological origin, such as the relative abundances of ontogenetic stages, sexual dimorphs, or higher taxa such as genera or families. The important corollary is that all the bed, beds or parts of a bed falling within a faunal horizon are, as far as can be judged from the fossils alone, effectively of the same age. They' may therefore be treated' each as equivalent to a single; faunally indivisible bed representing the sedi- ments of a negligible period of time - a geological instant. The local biostratigraphical succession has become a quantized, time-ordered sequence of distinguishable horizons, the biochronology of a succession of effectively brief events, separated by gaps of unknown duration that can be filled by the insertion of new horizons as they are discovered.

The geological record represented in this way is presumed at the outset to be incomplete. It is specified by two characteristic time-constants: $\delta t_{i}$, the duration of the time of formation of a faunal horizon, unknown but short; and $\delta t_{\mathrm{ij}}$, the time-interval between the times of formation $t_{\mathrm{i}}, t_{\mathrm{j}}$ of two horizons $\left.i, j \cdot \delta t_{\mathrm{ij}}\right\}$ is then the desired quantity, the temporal resolution achieved in the biostratigraphy of 
the characteristic fossils defining the faunal horizons. It depends strongly on these fossils. In the Jurassic, for instance, a standard Subzone (fig. 1) would on average contain around three ammonite faunal horizons. Two adjacent dinoflagellate floral horizons, however, defined as above, would be typically five or more ammonite Subzones apart.

Finally, it is interesting to represent the time-resolution achievable by mean of a given group of fossils in terms of a figure of merit relative to the ages $t_{\mathrm{i}}, t_{\mathrm{j}}$ of the rocks being considered. This may be expressed in terms of the temporal resolving-power,

$$
R=t_{\mathrm{i}} / \delta t_{\mathrm{ij}} .
$$

Some selected values of biochronological resolution and resolving-powers during the Phanerozoic are collected in Table 2. We note that these numerical estimates do now depend on the absolute values of geological ages, but only weakly so: their significance would not change very much even if the ages were in error by as much as 50\%.

\section{The limits of correlation by fossils: bioprovincialism}

Having discussed the limits to the temporal precision with which correlations can be made by means of fossils, with particular emphasis on the ammonites of the Mesozoic, the question arises: what sets the limits, if any, to the geographic extent over which correlations can be followed?

There are no marine organisms living today whose distribution is uniformly worldwide. The complex ecological interplay of substrates, marine climates and foodchains makes all habitats more or less restricted. There are no reasons to believe it was different in the past. But in the case of fossils, the only evidence we have is that of their distribution-patterns, which may be only indirectly related to the habitats of the organisms of which they are the remains, and the ecological factors responsible for them must remain largely unknown. For stratigraphical purposes, however, this is not important.

In the Mesozoic, the distributions of the best guidefossils, the ammonites, are restricted on both small and large scales of distance. The local, small-scale fluctuations are referred to as examples of facies-dependence, already mentioned previously. They affect the diversities and compositions of assemblages. The large-scale distribution-patterns are ascribed to bioprovincial endemisms, the restriction of occurrences to biogeographic provinces (see review by Kennedy \& Cobban 1976). The extents and durations of provincial endemisms varied from group to group even within the Ammonoidea, and could fluctuate with time. Faunal migrations could be large and geologically instantaneous, transitory or permanent. Faunal provinces could overlap or have no contact. There has gown up, therefore, a hierarchy of classification of de- grees of endemism, with a terminology derived from modern analogues - faunal Realms, Provinces, Subprovinces etc. The definition and delimitation of faunal Realms and Provinces tends to be, and is likely to remain, elastic depending on the particular group of organisms and range of strata under discussion.

Faunal provincialism was recognized in the Jurassic over a century ago (Neumayr 1883) and in the Cretaceous soon after. One of the first attempts at a comprehensive classification was made by Uhlig (1911) and many of the terms he introduced are still in use today. At the broadest level, we continue to differentiate the three major Realms: Boreal, Mediterranean (or Tethyan), and Pacific. At the next lower level, that of Provinces, some of the original names survive but almost always with a changed meaning, for the early attempts to discern biotic connections between different parts of the world took no account of the continental rearrangements brought about by plate tectonics. The effects of these could of course be dramatic. The Jurassic shelf-seas of Kenya, Madagascar, Kutch, the southern Himalayas and western Australia are scattered fragments of what was once a compact province, the Indo-Malagasy Province on the southern margins of the Tethyan Ocean of the time.

In trying to extend time-correlations over greater distances, therefore, what is a highly satisfactory biochronology worked out in one province may not be transferable to another. The way forward is to construct a biochronology in each province separately, complete with its own standard chronostratigraphical scale and nomenclature, and then to correlate these scales in regions of provincial overlap, if and where such can be found. The need for such an approach was first recognized in the Upper Jurassic, in which the bioprovincialism of the ammonites became so extreme that the faunas of adjacent provinces have nothing in common. So even today we use three parallel, provincial Stages for the top part of the Jurassic - Tithonian (Oppel 1865), Portlandian (d'Orbigny 1850) and Volgian (Nikitin 1881, 1884). Each has its own standard zonation, and correlations between them at zonal level continue to be highly tentative. Worse still, the correlations of their bases are uncertain to within a Zone; and worst of all, so are their upper boundaries, which are at the same time supposed to mark the unique, universal boundary between the Jurassic and Cretaceous Systems. The problem became acute already a little earlier, in the Oxfordian and Kimmeridgian. Here, two ammonite provinces are sharply differentiated. The Submediterranean Province, encompassing the northern margins of the Tethys from the Ibero-Lusitanian Basins, through Aquitaine and the southern Paris Basin, eastwards through the Rhodano-Franconian Basin (including the Jura and Helvetic Alps) and Galician Poland, extends as far as the northern Caucasus. The Subboreal Province includes East Greenland, Britain, Lower Saxony, the Baltic, most of Poland and the Volga Basin and extends into the Urals and western Siberia. Here, too, each Province has its own highly detailed standard zonation, down to 
Fig. 2. Standard zonation of the Middle Jurassic in two adjacent ammonite faunal provinces. The figure is drawn on a scale of equispaced Subzones along the left-hand column, equispaced faunal horizons 1-32 along the right. Correlation of the two zonations in the Bathonian remains impossible as no regions of provincial overlap are known. Provincial differentiation continues in the Upper Jurassic. (From Callomon 1993).

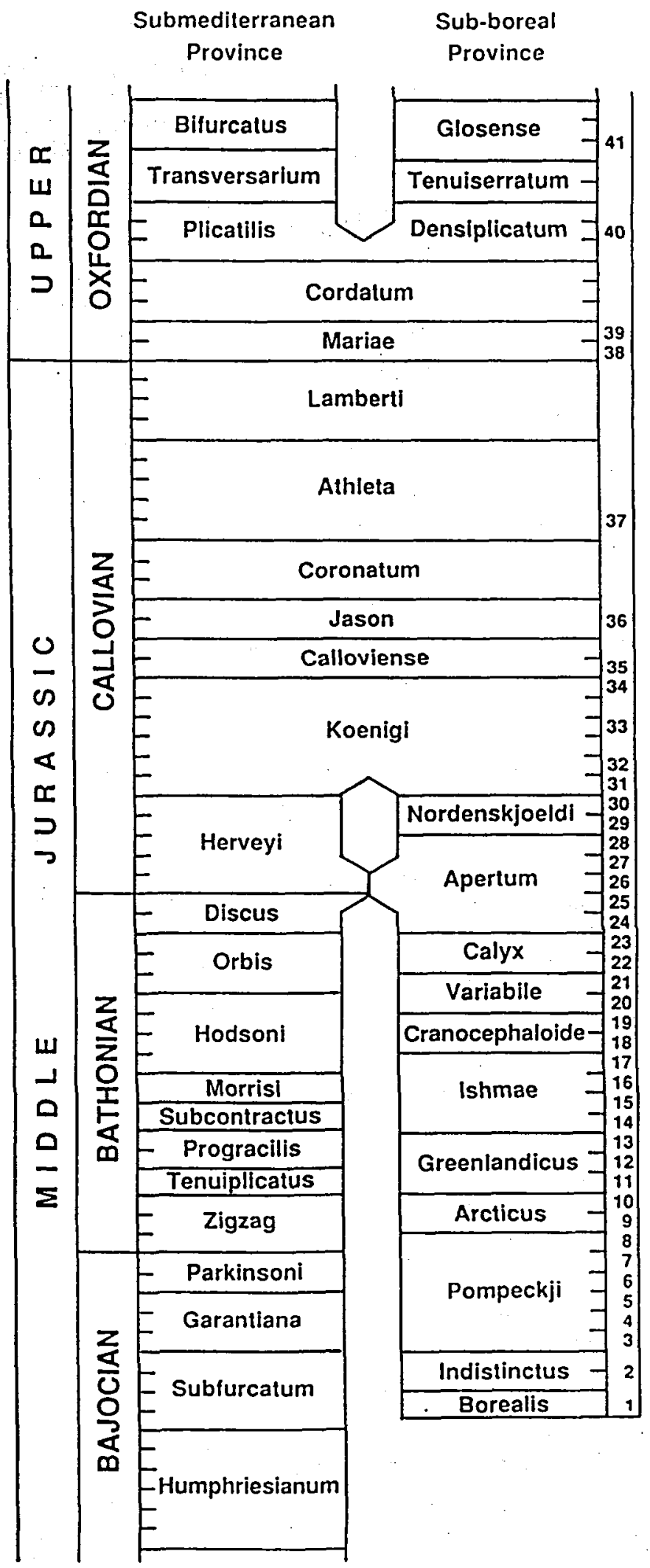




\begin{tabular}{|c|c|c|c|c|c|c|c|c|}
\hline & ENG & LAND & E GREENLAND & N \& NW SIBERIA & VOLC & A BASIN & & \\
\hline & Kochi & $\vdots$ & Kochi & Kochi & Kochi & & & \\
\hline & Runctoni & & (Maynci) & Sibiricus & Rjazane & & & \\
\hline & & & (Chetaites $\mathrm{sp}) \quad \mathrm{J} \mathrm{w}$ & Chetae & & & & \\
\hline & Lamplugh & hi & & Taimyrensis & Nodio & Nodiger & & \\
\hline & Preplicom & mphalus & & Originalis & & Mosquensis & 필 & \\
\hline & & & $\therefore$ & Okensis & -2 & Tokensis & 5 & \\
\hline & Primitivu & & Tenuicstas & Fvotion & Fulgens & \begin{tabular}{|l} 
Fulgens \\
\end{tabular} & & \\
\hline & 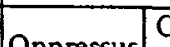 & Oppressus & $--z_{-}--_{1}$ & Exoticus & & $?$ & & \\
\hline & Uppressus & Anguiformis & & & & $?$ & & \\
\hline$z$ & Kerberus & & $\therefore$ & ? & Blakei & & & \\
\hline$\sum_{3}$ & Okusensis & & & Vogulicus & & ? & & \\
\hline$\approx$ & - Glaucolith & hus & Groenlandicus & Groenlandicus & & & ㅁ & \\
\hline & & & Anguinus & Crendonites spp & Nikitini & & $\overrightarrow{0}$ & \\
\hline & Albani & & Pseudapertum 4344 & Maximus & & Rosanovi & $\left.\frac{2}{\Sigma}\right|^{2}$ & \\
\hline & Fittoni & & $\begin{array}{l}\text { Gracilis } \\
\text { iostris }\end{array}$ & Ilovaiskii & Virgatus & Virgatus & & \\
\hline & Rotunda & & Communis & 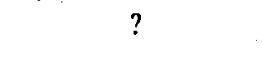 & Dar. & Zaraiskensis & & \\
\hline & & & Rugosa & $\widetilde{\text { Strajevskyi }}$ & Anden & Pavlowi & & \\
\hline$\leq$ & Pallasioid & & latriensis & latriensis & & $?$ & & \\
\hline 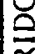 & & Paravirgatus & rinmus & & Tenuics & & & \\
\hline$\stackrel{\underline{n}}{=}$ & Pectinatus & \begin{tabular}{|l|} 
Eastlecott'sis \\
\end{tabular} & Pectinatus & Lideri & 1 enuice & tata & & \\
\hline$\sum_{y}$ & Hudiestoni & \begin{tabular}{|l|} 
Encombensis \\
Reisiformis \\
\end{tabular} & Hudlestoni & ? & Pseudo & ythica & & \\
\hline$\frac{2}{5}$ & Wheatley'sis & Wheatley'sis & Wheatleyensis & Subcrassum & & & 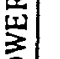 & \\
\hline & Scitulus & & Scituluse & Magnum & & & & \\
\hline & Elegans & & Elegans & $\cdot$ & Klimovi & & & \\
\hline
\end{tabular}

Fig. 3. Correlation chart for the Upper Jurassic Volgian in the Boreal Realm. The left-hand column is drawn to a scale of equispaced standard Zones in England as reference-scale. The numbers in the second column refer to ammonite faunal horizons in Milne Land; J: Jameson Land (Surlyk 1973); W: Wollaston Foreland (Surlyk 1978). (From Callomon \& Birkelund 1982).

Subzonal level, but the Oxfordian-Kimmeridgian boundary as at present conventionally drawn in the Submediterranean Province probably lies as much as a Zone higher than the level at which it is typologically defined at the boundary stratotype in Subboreal Britain (Sykes \& Callomon 1979, Atrops, Gygi, Matyja \& Wierzbowski 1994).

Since Arkell's global review of the Jurassic (1956), many additional provinces have come to be recognized.
They are now seen to be particularly prominent in the Middle Jurassic, and in previously less accessible parts of the world, revealed by the intensive exploration of the last 40 years, particularly of the Pacific (Westermann 1993) and in the Arctic. And it is to the latter that, by one of the accidents of geology, the Jurassic of Greenland, preserved onshore in small remnants on the east coast between 70 and $72^{\circ} \mathrm{N}$, has made leading contributions. 


\section{The Jurassic ammonite biochronology of East Greenland}

Jurassic rocks occur onshore in a narrow strip along the east coast of Greenland between 70 and $77^{\circ} \mathrm{N}$, but they are readily accessible, well exposed and richly fossiliferous in only two relatively small areas bordering Scoresbysund: in Jameson Land, for the Middle Jurassic, and in an erosional remnant resting on crystalline basement, in Milne Land. The sediments are all in wellbedded, cyclical shallow-water shelf or basinal siliclastic facies. A shore-line could not have been far away to the west, but direct evidence of its location has all been lost. The most remarkable feature, however, is the abundance of fossils, particularly ammonites. It is almost a hundred years since the first ones were brought back by the Danish expedition led by Amdrup and Harts in 1900. They were described by Madsen (1904). But their abundance was discovered during Lauge Koch's first expeditions, notably by Rosenkrantz and Aldinger (1935), and the descriptions of the early collections by Spath (1932, $1935,1936)$ continue to be of fundamental importance in Arctic palaeontology. The fossils are commonly concentrated at well-separated, narrow horizons, and the study of their biochronology lends itself almost ideally to the methods of faunal horizons described in the introduction. Beds are Ienticular and persist over distances of as little as $100 \mathrm{~m}$ up to tens of kilometres. The complete faunal succession has to be built up by integration, both horizontally and vertically, from many partial sections measured over the whole area. In Milne Land, ammonites were collected or recorded from over 50 sections in an area 10 $\mathrm{km}$ by $20 \mathrm{~km}$. In Jameson Land, 80 sections with ammonites were recorded in an area of $25 \mathrm{~km}$ by $125 \mathrm{~km}$.

The Lower Jurassic (Lias) follows conformably on Germanic Trias over most of Jameson Land but is developed largely in non-marine or very shallow, sublittoral quasi-marine facies. Fully marine incursions with diverse suites of fossils were infrequent, and ammonites have been found at only four horizons, in the Pliensbachian and Lower Toarcian. Correlation with Europe presents no problems and Greenland adds nothing to the general biochronology.

The ammonite biochronology of the Middle Jurassic has been recently reviewed in this journal (Callomon 1993). The number of faunal horizons that have been characterized is 38 . But the most important discovery has been that the lowest 30 or so of these horizons characterize a Middle Jurassic Boreal Province (Callomon 1985b) that extends over the whole of the Arctic, from northern Alaska through the Yukon (Poulton 1987) and Canadian Arctic Archipelago, Svalbard and the Barents Shelf, into the Petchora and the whole of northern Siberia (Meledina 1991). The results are summarized in fig. 2 .

This ammonite succession forms the basis for what has become accepted as the standard zonation for this part of the Jurassic over the whole of the Province. But as the figure shows, closer correlation below the Callovian with the rest of the world remains impossible: no regions of provincial overlap have yet been found. The closest approach so far is in the northern North Sea, to a point some $170 \mathrm{~km}$ ESE of the Shetlands (Callomon 1979). There is some roundabout evidence to suggest that the lowest three Zones - Borealis to Pompeckji - are still Upper Bajocian, but the Bajocian-Bathonian boundary as defined in Europe cannot be closely recognized anywhere in the Arctic (or in North and South America when it comes to it, for similar reasons).

The ammonite biochronology of the Upper Jurassic is even more complicated. In East Greenland it has yielded a succession of some 45 faunal horizons. The lowest 23 cover the Oxfordian and Kimmeridgian. Their correlation with Britain presents no problems (Callomon \& Birkelund 1980, Birkelund, Callomon \& Fürsich 1984), so during this time East Greenland belonged firmly in the Subboreal Province, as already described above, and contributes nothing new to the correlation of Subboreal and Submediterranean zonations. Upwards, however, in the Volgian, new faunal elements begin to appear. The position is summarized in fig. 3.

The Lower Volgian (faunas 24-30) also presents no difficulty in correlation with Britain, but the assemblages begin to contain minor elements whose true home is in Siberia. Thereafter, correlations with both Britain and the Russian Platform become more and more tenuous (faunas $31-47)$, through the intervention of a third province in the Boreal Realm. It has not so far received a separate definitive name and could be described as merely a continuation of the Boreal Province proper. It is characterized by the eudemic evolution (Callomon 1985b) of a separate lineage of perisphinctid ammonites of the genus Dorsoplanites that gave rise later to the Crasleditinae, Tolliinae, Polyptychitinae and Simbirskitinae, which dominated in the Arctic throughout the Neocomian and persisted into the Hauterivian. Its distribution ranged again from northern Alaska through the Yukon, the Canadian Arctic, all of East Greenland, Svalbard, Novaya Zemlya, to sub-polar western Siberia and across all of northern Siberia. The record remains patchy, and one of the important features brought out by the cross correlations in fig. 3 is the number of large gaps in fact present in almost all of the columns. But in the earlier Middle Volgian, the succession in East Greenland is again the most detailed and definitive one in its province, the Boreal province proper.

Altogether, then, the Middle and Upper Jurassic of East Greenland is characterized by nearly 100 faunal horizons of ammonites: Assuming a duration of this period of, say, 35 million years, this corresponds on average to time-resolutions of the order of 350,000 years, a figure excelled only in the classical areas of Europe with 150 years' intensive exploration behind them. 


\section{Conclusion}

This brief review has tried to outline the precision, resolution and geographic extent of time-correlations in Phanerozoic sediments that can be achieved by means of fossils. In favourable cases, such as the ammonites of the Jurassic, temporal resolutions can be as short as onethousandth of the age of the rocks, or the order of $100,000-200,000$ years. The distances over which precise correlations can be made are however limited by the bioprovincialism of most good guide-fossils. The Jurassic ammonites of East Greenland have provided outstanding examples of what can be achieved, and striking illustrations of the limitations set by bioprovincialism.

\section{References}

Aldinger, H. 1935: Geologische Beobachtungen im oberen Jura des Scoresbysundes (Ostgrønland). Meddelelser om Grønland 99, no.1, 128 pp.

Aldridge, R.J. 1987: Palaeobiology of Conodonts. 180 pp. Chichester: Ellis Horwood, for the British Micropalaeontological Society.

Arkell, W.J. 1956: Jurassic Geology of the World. xii + 681 pp. Edinburgh and London: Oliver \& Boyd.

Atrops, F., Gygi, R., Matyja, B.A. \& Wierzbowski, A. 1994: The Amoeboceras faunas in the Middle Oxfordian - lowermost Kimmeridgian Submediterranean succession and their correlative value. Acta geologica Polonica 43: 216-227.

Becker, R.T. 1993: Anoxia, eustatic changes, and Upper Devonian to lowermost Carboniferous global ammonoid diversity. In: House, M.R. (ed): The Ammonoidea. Systematics Association Special Volume 47: 115-164. Oxford: Clarendon press.

Birkelund, T., Callomon, J.H. \& Fürsich, F.T. 1984: The stratigraphy of the Upper Jurassic and Lower Cretaceous sediments of Milne Land, central East Greenland. Bulletin Grønlands Geologiske Undersøgélse 147: 1-56.

Buch, L. v. 1839; Über den Jura in Deutschland. Physikalische Abhandlungen der königlichen Akademie der Wissenschaften zu Berlin, Jahrgang 1837, 49-135.

Callomon, J.H. 1964: Notes on the Callovian and Oxfordian Stages. In: Maubeuge, P.L. (ed): Colloque du Jurassique à Luxembourg 1962, 269-291. Luxembourg: publications de l'Institut grandducal, section des sciences naturelles, physiques et mathematiques.

Callomon, J.H. 1979: Marine boreal Bathonian fossils from the northern North Sea and their palaeogeographic significance. Proceedings of the Geologists Association 90: 163-169.

Callomon, J.H. 1985a: Biostratigraphy, chronostratigraphy and all that - again! In: Michelsen, O. \& Zeiss, A. (eds): International Symposium on Jurassic Stratigraphy, Erlangen 1984, 3: 611-624. Copenhagen: Geological Survey of Denmark.

Callomon, J.H. 1985b: The evolution of the Jurassic ammonite family Cardioceratidae. Special papers in palaeontology 33: 49-90. London: palaeontological Association.

Callomon, J.H. 1993: The ammonite succession in the Middle Jurassic of East Greenland. Bulletin of the Geological Society of Denmark 40: 83-113.

Callomon, J.H. 1994: Palaeontological methods of stratigraphy and biochronology: some introductory remarks. In: Cariou, $\mathrm{E}$. \& Hantzpergue, P. (eds): 3e Colloque international sur le Jurassique, Poitiers 1991. Geobios, Memoire spécial 17: in press.

Callomon, J.H. 1995. Time from fossils: S.S. Buckman and
Jurassic high-resolution geochronology. In: LeBas, M. (ed), Time from Strata. Geological Society Special publication, in press.

Callomon, J.H. \& Birkelund, T. 1980: The Jurassic transgression and the mid-late Jurassic succession in Milne Land, central East Greenland. Geological Magazine 117: 211-226.

Callomon, J.H. \& Birkelund, T. 1982: The ammonite Zones of the Boreal Volgian (Upper Jurassic) in East Greenland. In: Embry, A.F. \& Balkwill, H.R. (eds): Arctic Geology and Geophysics. Canadian Society of Petroleum Geologists, Memoir 8: 349-369.

Harland, W.B., Armstrong, R.L., Cox, A.V., Craig, L.E., Smith, A.G. \& Smith, D.G. 1990: A geological time scale 1989. xi + 263 pp. Cambridge: University Press.

Hedberg, H.D. 1954: Procedures and terminology in stratigraphical classification. Congrès Géologique International. Comptes rendus de la XIX Session, Algers. Sect. XIII 1. partie, fasc. xiii, 205-233.

Kemper, E. 1978. Einige neue, biostratigraphisch bedeutsame Arten der Ammoniten-Gattung Dichotomites (NW-Deutschland, Obervalangin). Geologisches Jahrbuch, Hannover A45: 183-253.

Kennedy, W.J. \& Cobban, W.A. 1976. Aspects of ammonite biology, biogeography and biostratigraphy. Special Papers in Palaeontology 17: 94 pp. London: Paleontological Association.

Madsen, V. 1904. On Jurassic fossils from East-Greenland. Meddelelser om Grønland 29: 157-211.

Meledina, S.V. 1991. Zonal'na skhema "borealnogo bata" nizhnego kelloveya Sibiri. (The zonal classification of the "Boreal Bathonian" in the Lower Callovian of Siberia). Trudy, Institut Geologiya i Geofisika Akademiya Nauk SSSR, Sibirskikh Otdelenia 769: 125-154. Novosibirsk.

Neumayr, M. 1883: Über klimatische Zonen während der Juraund Kreidezeit. Denkschriften der kaiserlichen Akademie der Wissenschaften, Wien, mathematisch-naturwissenschaftliche Klasse, 47: 277-310.

Nikitin, S.N. 1881: Die Juraablagerungen zwischen Rybinsk, Mologa und Myschkin an der oberen Wolga. Mémoires de l'Academie des Sciences de St. Petersbourg 28, no.5: 98 pp.

Nikitin, S.N. 1884: Allgemeine geologische Karte von Russland. Blatt 56: Jaroslawl. Mémoires du Comité géologique de St. Petersbourg 1, no.2: $136 \mathrm{pp}$.

Obradovich, J.D. \& Cobban, W.A. 1975: A time-scale for the Late Cretaceous of the Western Interior of North America. Geological Association of Canada, Special paper 13: 31-54.

Oppel, A. 1865: Die tithonische Etage. Zeitschrift der Deutschen geologischen Gesellschaft 17: 535-558.

Orbigny, A. d' 1850 . Paléontologie francaise, terrains oolithiques ou Jurassiques. Tome premier: Céphalopodes, 521-632. Paris.

Palmer, A.R. 1977: Biostratigraphy of the Cambrian System - a progress report. Annual Reviews of Earth and Planetary Sciences 5: 13-33.

Poulton, T.P. 1987. Zonation and correlation of Middle Boreal Bathonian to Lower Callovian (Jurassic) ammonites, Salmon Cache Canyon, Porcupine River, northern Yukon. Geological Survey of Canada Bulletin 358: vii +155 pp.

Ramsbottom, W.H.C. 1977: Major cycles of transgression and regression (mesothems) in the Namurian. Proceedings of the Yorkshire Geological Society 41: 261-291.

Rickards, R.B. 1976. The sequence of the Silurian graptolite zones in the British Isles. Geological Journal, Liverpool 11: 153-188.

Riley, N.J. 1993: Biostratigraphy and chronostratigraphy of the Namurian Series in Britain. In: Cope, J.C.W., High resolution biostratigraphy. Geological Society Special Publication 70: 260.

Spath, L.F. 1932. The invertebrate faunas of the BathonianCallovian deposits of Jameson Land (East Greenland). Meddelelser om Grønland 87, no.7: $158 \mathrm{pp}$.

Spath, L.F. 1935-36. The Upper Jurassic invertebrate faunas of 
Cape Leslie, Milne Land. I. Oxfordian and Lower Kimmeridgian. Meddelelser om Grønland 99, no.2: 82 pp. (1935). II. Upper Kimmeridgian and Portlandian. Id., no.3: 180 pp. (1936).

Steno, N. 1669. De solido intra solidum naturaliter contento dissertationis prodromus. Florence.

Surlyk, F. 1973: The Jurassic-Cretaceous boundary in Jameson Land, East Greenland. In: Casey, R. \& Rawson, P.F. (eds): The Boreal Lower Cretaceous. Geological Journal, Liverpool, Special Issue 5: 81-100.

Surlyk, F. 1978: Submarine fan sedimentation along fault-scarps on tilted fault blocks (Jurassic-Cretaceous boundary, East Greenland). Bulletin Grønlands Geologiske Undersøgelse 128: $117 \mathrm{pp}$.

Sweet, W.C. 1988: The Conodonts. Oxford Monographs on Geology \& Geophysics 10. Oxford: Clarendon Press.

Sykes, R.M. \& Callomon, J.H. 1979. The Amoeboceras zonation of the Boreal Upper Oxfordian. Palaeontology 22: 837901.
Thomas, A.T., Owens, R.M. \& Rushton, A.W.A. 1984: Trilobites in British stratigraphy. Geological Society Special Report 16: $78 \mathrm{pp}$

Tozer, E.T. 1984: The Trias and its ammonoids: the evolution of a time scale. Geological Survey of Canada Miscellaneous Reports 35: $171 \mathrm{pp}$.

Uhlig, V. 1911: Die marinen Reiche des Jura und der Unterkreide. Mittheilungen der Geologischen Gesellschaft zu Wien, Jahrgang 4, Heft 3: 329-448.

Westermann, G.E.G. 1993: The Jurassic of the Circum-Pacific. $676 \mathrm{pp}$. New York: Cambridge University Press.

Ziegler, W. 1974: Conodont stratigraphy of the European Devonian. Memoirs of the Geological Society of America 127: 227-284.

Ziegler, W. \& Sandberg, C.A. 1990: The Late Devonian standard conodont zonation. Courier Forschungsinstitut Senckenberg 121: $115 \mathrm{pp}$. 